\title{
Omalizumab therapy in a patient with severe asthma and co-existing chronic obstructive pulmonary disease
}

\author{
Izabela Kupryś-Lipińska', Cezary Pałczyński², Joanna Molinska², Piotr Kuna
}

\begin{abstract}
1Department of Internal Medicine, Asthma and Allergy, Norbert Barlicki Memorial University Hospital No. 1, Medical University of Lodz, Lodz, Poland

${ }^{2}$ Department of Internal Medicine, Asthma and Allergy, Medical University of Lodz, Lodz, Poland
\end{abstract}

Adv Dermatol Allergol 2019; XXXVI (2): 239-241

DOI: https://doi.org/10.5114/ada.2018.73140

Exposure to tobacco smoke in asthmatics is one of the significant causes of severe asthma [1]. It is generally known that passive and active smoke exposure may induce asthma symptoms and bronchoconstriction in asthmatic patients [2]. Moreover, asthmatics who are regular smokers develop more severe asthma symptoms, have a lower quality of life and more often require emergency medical intervention and hospitalization due to exacerbations [3, 4]; their forced expiratory volume in $1 \mathrm{~s}$ $\left(\mathrm{FEV}_{1}\right)$ decline over time is faster [5] and their response to inhaled corticosteroids (ICSs) [6], even to higher doses $[7,8]$, is poorer. Apart from an active struggle with addiction, the treatment of an asthmatic smoker requires medications that overcome steroid resistance (long-acting $\beta_{2}$-adrenergic receptor agonists - LABA [9-11]) and have different mechanisms of action to corticosteroids (leukotriene receptor antagonist - LTRA [8, 12] and longacting muscarinic receptor antagonists - LAMA [13]). Little is known of the efficacy of anti-lgE biologic therapy in these patients.

The problem of smoking in asthmatics is not rare. Epidemiological data from the USA and Western Europe show that $17-35 \%$ of asthmatics [14] smoke cigarettes. In Poland, $17.9-19.7 \%$ of asthmatic patients are smokers, $16.9 \%$ ex-smokers and $31.86 \%[10,15]$ passive smokers.

This article presents the case of a 54-year-old patient, with a long-term history of smoking, who has been suffering from allergic bronchial asthma for about 20 years. She was referred to the clinic in January 2016 due to severe uncontrolled asthma that had occurred for 3 years. She had been treated chronically with high doses of ICSs and LABA, LAMA, LTRA, with theophylline periodically, short-acting $\beta$-agonist (SABA) as required and with oral corticosteroids for 3 months chronically. Despite the treatment, disease control was still unsatisfactory, with five acute exacerbations and two hospitalizations (in October and December) in 2015. An attempt was made to treat her with proton pump inhibitors (PPIs) despite the negative history of gastroesophageal reflux disease (GERD), but the therapy was ineffective. In addition, anxiolytic alprazolam treatment was introduced to alleviate mental state of the patient disturbed by recurrent exacerbations and hospitalization. The patient reported not smoking since January 2016, and before then smoking about 10 cigarettes a day for 20 years. Implementation of anti-IgE biologic therapy was considered (skin prick test - SPT) positive for allergens of house mites, cats and dogs, signs observed in dust exposure, clgE $483 \mathrm{IU} / \mathrm{ml}$ ).

Knowledge of the efficacy of omalizumab therapy in asthmatic smokers is based on observational studies conducted in countries where omalizumab therapy is not restricted by smoking status. In Spain, $4.1 \%$ of patients treated with omalizumab were smokers, $19.2 \%$ ex-smokers and $1.1 \%$ passive smokers [16]. A similar distribution of percentage rates relating to tobacco smoking was observed in an Italian cohort treated with omalizumab [17]: 3.6\% were current smokers, $27.1 \%$ ex-smokers and $68.6 \%$ had never smoked. On average, the current and ex-smokers reported 10 pack-years (0.5-67.5). However, while a multi-factor analysis of omalizumab efficacy, including smoking status, was conducted in the latter study, no such analysis was performed in the former. Unlike obesity and aspirin hypersensitivity, smoking had no impact on exacerbation occurrence in patients treated with omalizumab or asthma control measured with the Asthma Control Test (ACT).

In Poland, however, as in the UK, active smokers cannot receive publically funded anti-lgE therapy. A common definition of a non-smoker applied in epidemiologic research includes those who have never smoked and those who used to smoke in the past but no longer do, whereas an ex-smoker has smoked more than 100 cigarettes in

Address for correspondence: Izabela Kupryś-Lipińska MD, PhD, Department of Internal Medicine, Asthma and Allergy, Norbert Barlicki Memorial University Hospital No. 1, Medical University of Lodz, 22 Kopcinskiego St, 90-153 Lodz, Poland, phone: +48 606819702 , fax: +48 426781176 , e-mail: ikuprys@wp.pl Received: 4.12.2017, accepted: 13.12.2017. 
their lifetime but currently does not smoke [18]. In clinical trials a person who has not smoked for at least 6 months is considered "an ex-smoker". It is, however, an academic criterion not supported by any clinical trials, and the benefit of quitting smoking is observable even within $24 \mathrm{~h}$ following cessation.

Our patient was placed under observation to evaluate her determination not to smoke and the influence of cessation on disease control. Studies show that an improvement in pulmonary function parameters [19] may be observed 1 month following smoking cessation, and decreased bronchial hypersensitivity and improved asthma control after 6 weeks [20]. Nevertheless, in December 2016 the patient's asthma was still uncontrolled and severe exacerbations occurred (4 in the observation period, including 1 hospitalization). It was not possible to withdraw oral corticosteroids although the patient had not smoked. The patient was qualified for anti-lgE therapy. The first dose was administered in January 2017 (450 mg s.c. every 2 weeks, for clgE $893 \mathrm{lU} / \mathrm{ml}$ and $60 \mathrm{~kg}$ body weight). In weeks 16 and 46 of the therapy improvements in current asthma control $(\triangle \mathrm{ACQ}=0.8$ and $\triangle \mathrm{ACQ}$ $=0.5$ respectively) and quality of life $(\triangle \mathrm{AQLQ}=1.4$ and $\triangle \mathrm{AQLQ}=1.3$ respectively) were observed and complete corticosteroid withdrawal was successful. In that period the patient had two exacerbations, in the $1^{\text {st }}$ and $8^{\text {th }}$ month of therapy, related to a respiratory tract infection, but hospitalization was not required. Therapy efficacy was evaluated as good on the Global Evaluation of Treatment Effectiveness (GETE) scale. No improvement in pulmonary function or pulmonary exercise capacity was achieved.

The patient fulfils the spirometry chronic obstructive pulmonary disease (COPD) diagnosis criteria. Tobacco smoke exposure is a known significant etiologic factor in COPD. Epidemiological studies show that clinically active asthma itself is a factor increasing the risk of COPD development, even more significantly than smoking $(\mathrm{HR}=$ 12.5 for asthma and 2.9 for tobacco smoking) [21]. Global Initiative for Asthma (GINA) and Global Initiative for Chronic Obstructive Lung Disease (GOLD) guidelines suggest that therapy relevant to asthma severity should be applied in patients with asthma-COPD overlap, as signs of uncontrolled asthma are more dangerous than severe COPD. Experts do not express any opinion on use of biological medications in such cases.

Few case reports are available for asthmatics with coexisting COPD receiving omalizumab (1 from Japan [22], 3 from Turkey [23]), with different observation periods (from 36 days up to 1 year). These show improved disease control and fewer severe exacerbations.

A clinical improvement in asthma-COPD overlap in 10 patients was found to be accompanied by a decrease in fractional exhaled nitric oxide (FENO) as well as eosinophils, neutrophils, macrophages, eosinophil cationic protein (ECP) and sIL-4 levels in the systemic blood 1 year following therapy [24].

In 2017, the results of data analyses of 177 asthmatic patients, including 17 with diagnosed COPD, from the Australian register of patients treated with omalizumab were published. The therapy efficacy was evaluated after 6 months. Omalizumab therapy significantly improved asthma control and quality of life; however, it did not improve the pulmonary function ( $F_{1}$, forced vital capacity (FVC), $\mathrm{FEV}_{1} / \mathrm{FVC}$ ) in those with diagnosed COPD or FEV $<80 \%$ and smoking history.

To conclude, omalizumab appears to improve control of severe allergic asthma with coexisting COPD and this is the first Polish scientific report in this field as far as we know. Currently in Poland COPD co-occurrence is not a contraindication that prevents one from obtaining public funds [25] for biologic therapy, unlike active tobacco smoking [26].

\section{Conflict of interest}

I. Kuprys-Lipinska received personal fees for lectures from Novartis, P. Kuna received personal fees for lectures and advisory board activities from Novartis, J. Molinska and C. Palczynski declare no conflict of interest.

\section{References}

1. www.ginasthma.org. Światowa strategia rozpoznawania, leczenia i prewencji astmy. [Global Strategy for Asthma Management and Prevention]. Report 2015.

2. Higenbottam TW, Feyeraband C, Clark TJ. Cigarette smoking in asthma. Br J Dis Chest 1980; 74: 279-284.

3. Althuis MD, Sexton M, Prybylski D. Cigarette smoking and asthma symptom severity among adult asthmatics. J Asthma 1999; 36: 257-64.

4. Eisner MD, Yelin EH, Henke J, et al. Environmental tobacco smoke and adult asthma: the impact of changing exposure status on health outcomes. Am J Respir Crit Care Med 1998; 158: 170-5.

5. Lange P, Parner J, Vestbo J, et al. A 15-year follow-up study of ventilatory function in adults with asthma. N Engl J Med 1998; 339: 1194-200

6. Zheng X, Guan W, Zheng J, et al. Smoking influence response to inhaled corticosteroids in patients with asthma: a metaanalysis. Curr Med res Opin 2012; 28: 1791-8.

7. Pedersen B, Dahl R, Karlström R, et al. Eosinophil and neutrophil activity in asthma in a one-year trial with inhaled budesonide. The impact of smoking. Am J Respir Crit Care Med 1996; 153: 1519-29.

8. Lazarus SC, Chinchilli VM, Rollings NJ, et al. Smoking affects response to inhaled corticosteroids or leukotriene receptor antagonists in asthma. Am J Respir Crit Care Med 2007; 175: 783-90.

9. Clearie KL, McKinlay L, Williamson PA, Lipworth BJ. Fluticasone/Salmeterol combination confers benefits in people with asthma who smoke. Chest 2012; 141: 330-8.

10. Kupryś-Lipińska I. Skuteczność montelukastu w ambulatoryjnym leczeniu astmy oskrzelowej u pacjentów powyżej 15. roku życia w warunkach codziennej praktyki lekarskiej (real life study). Pediatr Med Rodz 2012; 8: 360-9. 
11. van Schayck OC, Haughney J, Aubier M, et al. Do asthmatic smokers benefit as much as non-smokers on budesonide/ formoterol maintenance and reliever therapy? Results of an open label study. Respir Med 2012; 106: 189-96.

12. Rabinovitch N, Strand M, Stuhlman K, Gelfand EW. Exposure to tobacco smoke increases leukotriene E4-related albuterol usage and response to montelukast. J Allergy Clin Immunol 2008; 121: 1365-71.

13. Magnussen H, Bugnas B, van Noord J, et al. Improvements with tiotropium in COPD patients with concomitant asthma. Respir Med 2008; 102: 50-6.

14. Thomson NC, Chaudhuri R, Livingston E. Asthma and cigarette smoking. Eur Respir J 2004; 24: 822-33.

15. Kuna P, Kupryś-Lipińska I, Dębowski T. Control of asthma in adults treated with beclomethasone and formoterol in extrafine particle formulation in a real-life setting in Poland: the CASPER noninterventional, observational trial. Pol Arch Med Wewn 2015; 125: 731-40.

16. Vennera Mdel C, Pérez De Llano L, Bardagí S, et al. Omalizumab therapy in severe asthma: experience from the Spanish registry-some new approaches. J Asthma 2012; 49: 416-22.

17. Novelli F, Latorre M, Vergura L, et al. Asthma control in severe asthmatics under treatment with omalizumab: a crosssectional observational study in Italy. Pulm Pharmacol Ther 2015; 31: 123-9.

18. Monitoring Tobacco Use in New Zealand. Available at: http://www.health.govt.nz/publication/monitoring-tobaccouse-new-zealand; Access: 31.03.2016.

19. Buist AS, Sexton GJ, Nagy JM, Ross BB. The effect of smoking cessation and modification on lung function. Am Rev Respir Dis 1976; 114: 115-22.

20. Westergaard CG, Porsbjerg C, Backer V. The effect of Varenicline on smoking cessation in a group of young asthma patients. Respir Med 2015; 109: 1416-22.

21. Silva GE, Sherrill DL, Guerra S, Barbee RA. Asthma as a risk factor for COPD in a longitudinal study. Chest 2004; 126: 59-65.

22. Gamo S, lijima H, Seki Y, et al. Omalizumab rescued a asthma-COPD overlap syndrome patient from a status asthmatics under the ICU management. Arerugi 2016; 65: 937-41.

23. Tat TS, Cilli A. Omalizumab treatment in asthma-COPD overlap syndrome. J Asthma 2016; 53: 1048-50.

24. Yalcin AD, Celik B, Yalcin AN. Omalizumab (anti-lgE) therapy in the asthma-COPD overlap syndrome (ACOS) and its effects on circulating cytokine levels. Immunopharmacol Immunotoxicol 2016; 38: 253-6.

25. Protokół Nr 47 z posiedzenia Zespołu Koordynacyjnego ds. Leczenia Biologicznego Ciężkiej Astmy Alergicznej z dnia 13 czerwca 2017 roku. Available at: http://www.nfz.gov.pl/ dla-swiadczeniodawcy/zespoly-koordynujace/ciezka-astmaalergiczna-protokoly,8.html

26. Obwieszczenie Ministra Zdrowia z dnia 28 sierpnia 2017 r. w sprawie wykazu refundowanych leków, środków spożywczych specjalnego przeznaczenia żywieniowego oraz wyrobów medycznych (DZ. URZ. Min. Zdr. 2017.87). Załącznik B.44. Available at: http://www.mz.gov.pl/leki/refundacja/lista-lekow-refundowanych-obwieszczenia-ministrazdrowia/ 